\title{
Should patients with anogenital warts be tested for genital herpes? Initial results of a pilot study
}

\author{
Funda Tamer ${ }^{1}$, Mehmet Eren Yuksel ${ }^{2}$, Emine Avcı ${ }^{3}$
}

${ }^{1}$ Ufuk University School of Medicine, Department of Dermatology, Ankara, Turkey, ${ }^{2}$ Aksaray University School of Medicine, Department of General Surgery, Aksaray, Turkey, ${ }^{3}$ General Directorate of Public Health, Department of Infectious Diseases, Ankara, Turkey

Corresponding author: Dr. Funda Tamer, E-mail: fundatmr@yahoo.com

\begin{abstract}
Background: Genital warts are manifestations of a disease caused by human papillomavirus. Genital warts usually present as multiple, asymmetric, polymorphic papular lesions on the anogenital skin and mucous membranes. Patients with genital warts may have coexisting sexually transmitted diseases. Appropriate screening is crucial to prevent the spread of these infections for public health. Materials and Methods: The study included 20 patients with anogenital warts and 20 healthy individuals within the control group. Laboratory tests including serum levels of hepatitis B surface antigen, antibody to hepatitis B surface antigen, hepatitis $\mathrm{C}$ antibody, anti human immunodeficiency virus antibody, herpes simplex virus type-l IgG and herpes simplex virus type-2 IgG were evaluated in each participant. Venereal Disease Research Laboratory test was also evaluated in the patient group. Results: Serum levels of hepatitis $\mathrm{B}$ surface antigen, hepatitis $\mathrm{C}$ antibody and anti human immunodeficiency virus antibody were negative in all patients and healthy individuals. Serum levels of antibody to hepatitis B surface antigen were positive in 15(75\%) patients and in $14(70 \%)$ healthy individuals $(\mathrm{p}=1)$. Venereal Disease Research Laboratory test was non-reactive in all patients with anogenital warts. Serum herpes simplex virus type-l IgG levels were positive in 14(70\%) patients and in $11(55 \%)$ healthy individuals $(\mathrm{p}=0.51)$. Serum herpes simplex virus type-2 IgG levels were positive in $4(20 \%)$ patients while all the healthy individuals had negative serum herpes simplex virus type-2 $\operatorname{IgG}$ levels $(\mathrm{p}=0.03)$. Conclusions: Positive serum herpes simplex virus type-2 IgG levels were significantly more frequent in patients with anogenital warts compared to healthy individuals. Therefore, we suggest that all the patients with anogenital warts should be tested for genital herpes. Hereby, the preliminary results of laboratory tests for the evaluation of patients with anogenital warts have been reported.
\end{abstract}

Key words: Condylomata Acuminata; Genital; Herpes Simplex; Human Papillomavirus; Warts

\section{INTRODUCTION}

Sexually transmitted diseases like genital wart, genital herpes, syphilis, human immunodeficiency virus (HIV) infection remain a worldwide public health problem [1]. Hepatitis B has also been regarded as a sexually transmitted infection for years. Hepatitis C virus can be transmitted sexually especially in HIV positive patients [2]. Sexually transmitted diseases affect both men and women during the reproductive years. Most of the patients with sexually transmitted diseases (86\%) are between the ages of 15 to 29 [1].
Genital warts are caused by human papillomavirus (HPV) which is the most common sexually transmitted virus worldwide. More than 200 types of HPV have been described yet and for about 40 types of HPV can lead to benign or malign lesions in the genital area [3]. It has been suggested that over $99.7 \%$ patients with cervical cancer had positive HPV test results [4]. Genital warts may coexist with other sexually transmitted diseases. Therefore, appropriate screening for sexually transmitted diseases is recommended in all patients presenting with genital warts [4].

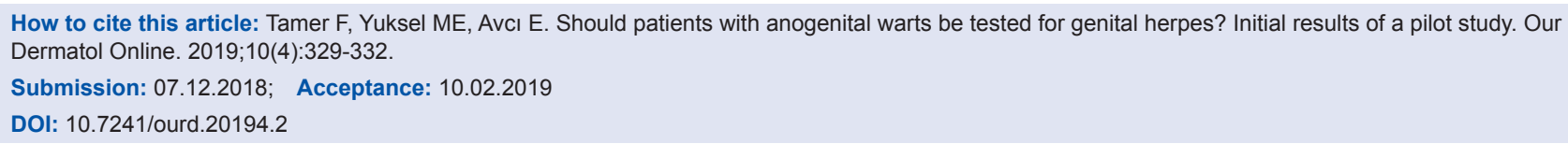


Genital herpes is the most common genital ulcerative disorder primarily caused by herpes simplex virus type2 (HSV2) or herpes simplex virus type-l (HSVl) [5]. Herpes simplex virus type-2 is shed in the genital tract asymptomatically. Transmission of the virus usually occurs during periods of asymptomatic viral shedding [6].

Interaction between HPV and HSV has been associated with cervical carcinogenesis. Herpes simplex virus infection and replication may induce cytopathic effects in HPV-positive tissues [7]. Herpes simplex virus type-2 infection is considered as a facilitative factor in cancer development [8]. Sexually transmitted disease prevention and treatment programs are crucial to reduce the transmission of these infections [9].

\section{MATERIALS AND METHODS}

The study included 20 patients with genital warts and 20 healthy individuals within the control group. Medical records of the participants were reviewed retrospectively between May 2017 and May 2018. The exclusion criteria were pregnancy, immunosuppression, malignancy and conditions which require regular blood transfusions like anemia, thrombocytopenia, hemophilia and chronic kidney disease.

Laboratory tests including serum levels of hepatitis B surface antigen (HBsAg), antibody to hepatitis B surface antigen (anti-HBs), hepatitis C antibody (anti-HCV), anti human immunodeficiency virus antibody (anti-HIV), herpes simplex virus type-1 (HSVl) IgG and herpes simplex virus type-2 (HSV2) $\mathrm{IgG}$ were evaluated in each participant. Venereal Disease Research Laboratory (VDRL) test results were evaluated in patient group.

All patients with genital warts were treated with cryotherapy. The therapy was performed every three weeks, for a maximum of five treatment sessions. The patients were adviced to use mupirocin $2 \%$ cream twice daily, after the cryotherapy treatment.

Data were analyzed using SPSS 20.0 Statistical Package Program. Descriptive statistics were presented as number and percentage for classified data, and as mean \pm standard deviation or median (minimum; maximum) for numerical values. The chi-square test was used to compare categorical variables between patient group and healthy individuals. As the numerical variables were not normally distributed, groups were compared using non-parametric tests. Differences between two independent groups were tested with Mann Whitney $\mathrm{U}$ test. The $\mathrm{p}$-value $<0.05$ was considered significant.

\section{RESULTS}

The study included 20 patients with genital warts and 20 healthy individuals within the control group. Each group consisted of 17 (85\%) male and 3 (15\%) female participants. The mean age of the patients was $30.8 \pm 8.2$ (range: $20-52$ ). The mean age of the healthy individuals was $31.6 \pm 9.7$ (range: 19-58) $(\mathrm{p}=0.9)$.

The mean disease duration of the patients with genital warts was 6.6 6.5 months (range: 1-24 months). Twelve (60\%) patients did not receive any treatment previously. One $(5 \%)$ patient used topical imiquimod $5 \%$ cream (Aldara ${ }^{\circledR}$ ) three times per week for two months. Seven (35\%) patients were treated with 1 to 5 sessions of cryotherapy twice monthly.

Venereal Disease Research Laboratory test was nonreactive in all patients with anogenital warts (Table 1 ).

The mean serum HBsAg level was $0.32 \pm 0.15 \mathrm{~S} / \mathrm{CO}$ in patients (range: negative $<1$, positive $>1 \mathrm{~S} / \mathrm{CO}$ ). The mean serum HBsAg level was $0.23 \pm 0.04 \mathrm{~S} / \mathrm{CO}$ in healthy individuals $(\mathrm{p}=0.03)$. Serum HBsAg levels were negative in all patients and healthy individuals.

The mean serum anti-HBs level was 305.44 $391.64 \mathrm{mIU} / \mathrm{mL}$ in patients (range: negative: 0-10, positive: $10-1000 \mathrm{mIU} / \mathrm{mL}$ ). The mean serum anti-HBs level was $83.88 \pm 99.82 \mathrm{mIU} / \mathrm{mL}$ in healthy individuals $(\mathrm{p}=0.29)$. Serum anti-HBs levels were positive in $15(75 \%)$ patients and negative in $5(25 \%)$ patients. Serum anti-HBs levels were positive in

Table 1: Laboratory test results of the patients with genital warts and healthy individuals

\begin{tabular}{lccc}
\hline $\begin{array}{l}\text { Positive test } \\
\text { results }\end{array}$ & Patients $(\mathbf{n = 2 0})$ & $\begin{array}{c}\text { Healthy } \\
\text { individuals }(\mathbf{n = 2 0})\end{array}$ & p-value \\
\hline VDRL & 0 & - & \\
HBsAg & 0 & 0 & 1 \\
Anti-HBs & $15(75 \%)$ & $14(70 \%)$ & \\
Anti-HCV & 0 & 0 & \\
Anti-HIV & 0 & 0 & 0.51 \\
HSV1lgG & $14(70 \%)$ & $11(55 \%)$ & 0.03 \\
HSV2IgG & $4(20 \%)$ & 0 & \\
\hline
\end{tabular}

Serum levels of HBsAg, anti-HCV and anti-HIV were all negative in patients and healthy individuals. Serum VDRL test results were negative in patient group. Frequency of positive serum levels of anti-HBs and HSV1lgG were similar in both groups. However, positive HSV2lgG levels were significantly more prevalent in patients with genital warts compared to healthy individuals $(p=0.03)$. 
$14(70 \%)$ healthy individuals and negative in 6(30\%) healthy individuals $(\mathrm{p}=1)$.

The mean serum anti-HCV level was $0.06 \pm 0.02$ $\mathrm{S} / \mathrm{CO}$ in patients (range: negative: $0-1$, positive: 1.45-1000 S/CO). The mean serum anti-HCV level was $0.05 \pm 0.02 \mathrm{~S} / \mathrm{CO}$ in healthy individuals $(\mathrm{p}=0.78)$. Serum anti-HCV levels were negative in all patients and healthy individuals.

The mean serum anti-HIV level was $0.16 \pm 0.13 \mathrm{~S} / \mathrm{CO}$ in patients (range: negative: $0.01-1$, positive: $1-1000 \mathrm{~S} /$ $\mathrm{CO})$. The mean serum anti-HIV level was $0.12 \pm 0.04$ $\mathrm{S} / \mathrm{CO}$ in healthy individuals $(\mathrm{p}=0.62)$. Serum antiHIV levels were negative in all patients and healthy individuals.

The mean serum herpes simplex virus type-1 IgG (HSV1IgG) level was $104.99 \pm 76.77 \mathrm{RU} / \mathrm{mL}$ in patients (range: negative $<16$, positive $>22 \mathrm{RU} / \mathrm{mL}$ ). The mean serum HSV1 IgG level was 90.34 $\pm 83.49 \mathrm{RU} / \mathrm{Ml}$ in healthy individuals $(\mathrm{p}=0.62)$. Serum HSV1IgG levels were positive in $14(70 \%)$ patients and negative in $6(30 \%)$ patients. Serum HSV1 IgG levels were positive in $11(55 \%)$ healthy individuals and negative in $9(45 \%)$ healthy individuals $(\mathrm{p}=0.51)$.

The mean serum herpes simplex virus type-2 IgG (HSV2IgG) level was $16.21 \pm 41.10 \mathrm{RU} / \mathrm{mL}$ in patients (range: negative $<16$, positive $>22 \mathrm{RU} / \mathrm{mL}$ ). The mean serum HSV2IgG level was $2.30 \pm 2.47 \mathrm{RU} / \mathrm{mL}$ in healthy individuals $(\mathrm{p}=0.73)$. Serum HSV2IgG levels were positive in $4(20 \%)$ patients and negative in $16(80 \%)$ patients. All of the healthy individuals had negative serum HSV2IgG levels $(\mathrm{p}=0.03)$.

\section{DISCUSSION}

Genital warts (condylomata acuminata) are manifestations of a sexually transmitted disease usually caused by HPV type 6 and 11. Genital warts are more common in men than in women. They usually present as multiple, asymmetric, exophytic lesions, plane papules or cauliflower-like growths in the anogenital region [10]. In addition, genital warts may occur as a giant mass which is called Buschke-Loewenstein tumor [11]. The diagnosis of genital wart is usually made based on clinical findings. However, a biopsy should be performed to painful, bleeding, ulcerated and therapy-resistant lesions in order to reach a definitive diagnosis [10]. The differential diagnosis should include verrucous cancer of the vulva, condyloma lata, skin tag, lichen planus, sebaceous cyst and pearly penile papules $[10,12]$. Treatment of choice includes topical use of podophyllotoxin, imiquimod and trichloroacetic acid, electrocauterization, cryotherapy, laser therapy and surgical excision [13]. Cryotherapy is one of the most commonly used and effective method with low complication rates [14]. However, surgical excision is needed for large and resistant warts, also for lesions suspicious for malignancy, and for warts which cause obstruction [15].

Genital warts may also be the manifestations of high-risk HPV types (HPV 16, 18, 31, 33, 35, 39, 45, $51,52)$ which are associated with low/high grade squamous intraepithelial lesions and invasive cancer. The relationship between HPV infection and cervical cancer has been well established. Moreover, oncogenic strains of HPV play role in the development of anal cancer. Genital warts can be localized both externally and internally within the anal canal and lower rectum. Therefore, cervical pap smear, anoscopy and proctosigmoidoscopy are essential in the management of patients with anogenital warts [16].

Patients with genital warts should be screened for coinfections with other sexually transmitted diseases [17]. Casillas-Vega et al. reported that HIV positive patients were more likely to have HPV infection and HSV2 positive patients were more likely to be infected with Mycoplasma genitalium. Moreover, patients infected with Trichomonas vaginalis were more likely to have syphilis and infections with HPV, HIV, HSVl and also Mycoplasma genitalium [18]. Alberts et al. reported that HPV prevalence was higher in HSV-2 seropositive men than in HSV-2 seronegative men [19]. Peters et al. evaluated 66 patients with symptoms of sexually transmitted diseases. Coinfection rates of HSV in syphilis and HIV positives were $40.6 \%$ and $42.9 \%$ respectively [20]. Agyemang-Yeboah et al. reported that the prevalence of HSV1 and HSV2 infection among HPV positive women were $98.6 \%$ and $80.4 \%$, respectively [21].

Within this study, none of the patients with genital warts had syphilis, active hepatitis B, active hepatitis C or HIV infection. Moreover, the frequency of positive serum HSV IIgG levels were similar in patients with genital warts and healthy individuals.

Herpes simplex virus type-2 plays a synergetic role with HPV in the development of malignant changes in HPV-positive tissues [7,22]. Transmission of HSV2 
to an uninfected individual usually occurs during asymptomatic reactivation of the virus. Antiviral treatment may decrease the incidence of HSV2 infection by preventing HSV2 shedding [6]. Within this study, detection of positive serum HSV2IgG levels were statistically more frequent in patients with genital warts compared to healthy individuals. These results suggest that screening of patients with genital warts for genital herpes may be helpful in the management of HSV2 spreads and cytopathic effects of co-infection of HSV2 and HPV.

Hereby, the preliminary results of laboratory tests for the evaluation of patients with anogenital warts have been reported. Further studies with larger sample size are required to confirm our data.

\section{Statement of Human and Animal Rights}

All procedures followed were in accordance with the ethical standards of the responsible committee on human experimentation (institutional and national) and with the Helsinki Declaration of 1975, as revised in 2008.

\section{Statement of Informed Consent}

Informed consent was obtained from all patients for being included in the study.

\section{REFERENCES}

1. Puri N, Kumari P. A study on sexually transmitted diseases in patients in a STD clinic in a district hospital in North India. Our Dermatol Online. 2014;5:240-4.

2. Brook MG. Sexually acquired hepatitis. Sex Transm Inf. 2002;78:235-40.

3. Suligoi B, Vittori G, Salfa MC, Timelli L, Corsini D, Fattorini G, et al. Prevalence and incidence of external genital warts in a sample of Italian general female population. BMC Infect Dis. 2017;17:126.

4. Ooi C. Testing for sexually transmitted infections. Aust Prescr. 2007;30:8-13.

5. Parajuli S, Acharya Y, Rathi SB, Paudel U. Chronic ulcerating genital herpes simplex virus infection: a diagnosis mislead by HIV infection. Our Dermatol Online. 2014;5:285-6.

6. Schiffer JT, Mayer BT, Fong Y, Swan DA, Wald A. Herpes simplex virus-2 transmission probability estimates based on quantity of viral shedding. J R Soc Interface. 2014;11:20140160.

7. Meyers C, Andreansky SS, Courtney RJ. Replication and interaction of herpes simplex virus and human papillomavirus in differentiating host epithelial tissue. Virology. 2003;315:43-55.

8. Yun H, Park J, Choi I, Kee M, Choi B, Kim S. Prevalence of human papillomavirus and herpes simplex virus type 2 infection in Korean commercial sex workers. J Microbiol Biotechnol. 2008;18:350-4.

9. Yared N, Horvath K, Fashanu O, Zhao R, Baker J, Kulasingam S. Optimizing screening for sexually transmitted infections in men using self-collected swabs: a systematic review. Sex Transm Dis. 2018;45:294-300.

10. Steben M, Garland SM. Genital warts. Best Pract Res Clin Obstet Gynaecol. 2014;28:1063-73.

11. Al Aboud K, Al Aboud A. Eponyms in dermatology literature linked to genital skin disorders. Our Dermatol Online. 2013;4:243-6.

12. Puri N, Puri A. A study on non-venereal genital dermatoses in north India. Our Dermatol Online. 2013;4:304-7.

13. Wiley DJ, Douglas J, Beutner K, Cox T, Fife K, Moscicki AB, et al. External genital warts: diagnosis, treatment, and prevention. Clin Infect Dis. 2002;35:210-24.

14. Thapa DP, Jha AK, Shrestha S, Joshi S. Cryosurgery in a dermatology setup: a hospital based study. Our Dermatol Online. 2018;9:137-9.

15. Yanofsky VR, Patel RV, Goldenberg G. Genital warts: a comprehensive review. J Clin Aesthet Dermatol. 2012;5:25-36.

16. Chang GJ, Welton ML. Human papillomavirus, condylomata acuminata, and anal neoplasia. Clin Colon Rectal Surg. 2004;17:221-30.

17. Carne CA, Dockerty G. Genital warts: need to screen for coinfection. BMJ. 1990;300:459.

18. Casillas-Vega N, Morfín-Otero R, García S, Llaca-Díaz J, RodríguezNoriega E, Camacho-Ortiz A, et al. Sexually transmitted pathogens, coinfections and risk factors in patients attending obstetrics and gynecology clinics in Jalisco, Mexico. Salud Publica Mex. 2016;58:437-45.

19. Alberts CJ, Schim van der Loeff MF, Papenfuss MR, da Silva RJ, Villa LL, Lazcano-Ponce E, et al. Association of Chlamydia trachomatis infection and herpes simplex virus type 2 serostatus with genital human papillomavirus infection in men: the HPV in men study. Sex Transm Dis. 2013;40:508-15.

20. Peters BP, Rastogi VL, Monica, Nirwan PS. Coinfection of HSV with other sexually transmitted diseases. Indian J Med Microbiol. 2005;23:143-4.

21. Agyemang-Yeboah F, Debrah O, Donkoh ET, Asmah HR, Seini MM. Co-infection prevalence of herpes simplex virus types 1 and 2 with human papillomavirus and associated risk factors among asymptomatic women in Ghana. Int J Inf Dis Ther. 2018;3:45-51.

22. Raju K. Virus and cervical cancer: role and implication: a review. Biomed Res Ther. 2015;2:220-30.

Copyright by Funda Tamer, et al. This is an open-access article distributed under the terms of the Creative Commons Attribution License, which permits unrestricted use, distribution, and reproduction in any medium, provided the original author and source are credited.

Source of Support: Nil, Conflict of Interest: None declared. 